Authors: A Rieu-Clarke and C Spray

ECOSYSTEM SERVICES AND INTERNATIONAL WATER LAW:

TOWARDS A MORE EFFECTIVE DETERMINATION AND

IMPLEMENTATION OF EQUITY?

ISSN 1727-3781

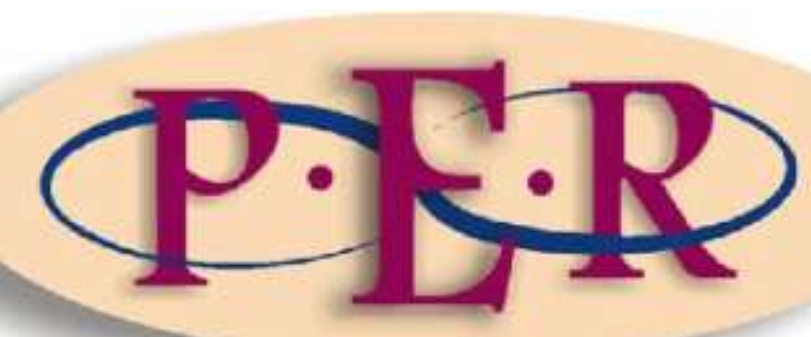

2013 VOLUME 16 No 2

http://dx.doi.org/10.4314/pelj.v16i2.3 


\section{ECOSYSTEM SERVICES AND INTERNATIONAL WATER LAW: TOWARDS A MORE EFFECTIVE DETERMINATION AND IMPLEMENTATION OF EQUITY?}

\section{A Rieu-Clarke and C Spray*}

\section{$1 \quad$ Introduction}

Interest in an ecological- or an ecosystem-centred approach to natural resource management is not new, and in the case of water management has been very well emphasised for many decades. In a formal sense it can be argued that this began with the inception of the focus on the linkages between land and water management, through Integrated Water Resource Management (IWRM), even before its framing within the Dublin principles and subsequent championing by the Global Water Partnership. ${ }^{1}$

More recently though, the utility and effectiveness of the IWRM approach has been challenged, ${ }^{2}$ whilst an additional element has emerged with the more formal framing of elements of an integrated approach to natural resource management, as defined by the Convention on Biological Diversity's definition and promotion of the Ecosystem Approach. ${ }^{3}$

Most recently, the debate has moved on again, with the publication in 2005 of the Millennium Ecosystem Assessment (MA), and an even greater focus on ecosystem services and the connection between healthy functioning ecosystems and human

Alistair Rieu-Clarke. LLB (Hons), LLM (Distinction), PhD. Reader in International Law, Centre for Water Law, Policy \& Science (under the auspices of UNESCO), University of Dundee. Email: a.rieuclarke@dundee.ac.uk

Christopher Spray. MA (Cantab); PhD; Chair of Water Science and Policy, Centre for Water Law, Policy \& Science (under the auspices of UNESCO), University of Dundee. Email: C.J.Spray@dundee.ac.uk

Global Water Partnership Technical Advisory Committee Integrated Water Resources Management.

2 See for example Biswas 2004 Water International 248-256; Biswas 2008 Journal of Water Resources Development 5-22; Mitchell 2005 Environment and Planning 1335-1352; Cook and Spray 2012 Journal of Environmental Management 109, 93-100.

UN Convention on Biological Diversity (1992). 
well-being. ${ }^{4}$ The Economics of Ecosystem and Biodiversity (TEEB) report has also highlighted that by failing to take proper account of wildlife and the natural environment, politicians and others are effectively ignoring the value of ecosystems to economies and society, and risk making the wrong decisions in responding to challenges of resource allocation, both locally and globally. ${ }^{5}$

Whilst the links between IWRM and legal frameworks and practices that define and promote the equitable and reasonable utilisation of water resources have been well rehearsed and debated, ${ }^{6}$ the emergence of what some have seen as a new scientific paradigm concerning ecosystem services ${ }^{7}$ raises the question as to how or if this can aid the legal bases for effective transboundary water management.

In this regard, water and wetland ecosystems are perhaps among the best studied of habitats in terms of ecosystem services, ${ }^{8}$ particularly in relation to potential mechanisms for payments for ecosystem services (PES) schemes. ${ }^{9}$ Rarely have such studies seriously considered the transboundary nature of ecosystems, and - at least from a legal perspective - the feasibility of adopting an ecosystem services paradigm between sovereign states. In fact law in general has lagged behind other disciplines, such as economics, geography and ecology, in the analysis of ecosystem services. ${ }^{10}$ Feldman, even goes as far as to say ${ }^{11}$

perhaps the most salient missing formulation in the current policy assessment for ecosystems services, the one added factor that would ensure successful safeguarding and provisioning of ecosystem services, is the legal and regulatory policy component.

The lack of attention to ecosystem services within the context of transboundary freshwater ecosystems and law might be contrasted with the extent of the resource.

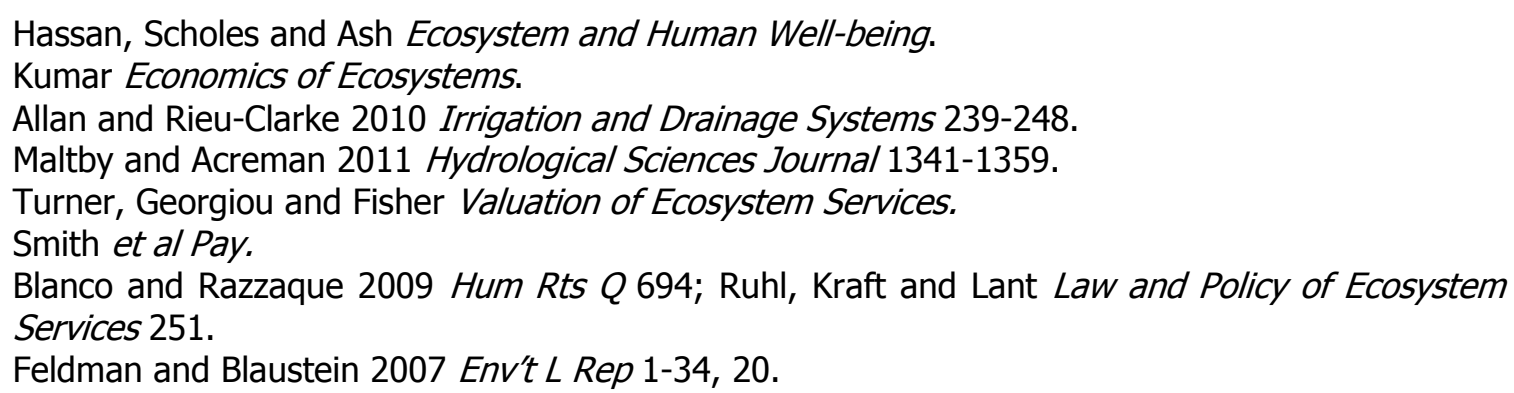


There are 263 rivers shared between sovereign states, and around 200 transboundary aquifers. ${ }^{12}$ The world's transboundary river basins account for nearly one-half of the earth's surface area, create around 60 per cent of global freshwater flow, and are home to approximately 40 per cent of the world's population. ${ }^{13}$ However, it is perhaps the political aspects of transboundary freshwaters that raise most alarm. 145 countries have their territories, at least in part, within the 263 transboundary river basins. In addition, through the advent of globalisation and increased international trade most states rely upon the goods and services produced off the back of transboundary freshwaters, as well as waters completely separated from their own territorial area or jurisdiction. It is therefore not surprising that water is considered to be a national, regional and global security issue. ${ }^{14}$ Former UN Secretary-General Kofi-Annan has even warned that, "environmental stress due to lack of water may lead to conflict and would be greater in poor nations". ${ }^{15}$

In seeking to address the challenges of sharing water between sovereign states, a significant body of international law has emerged. ${ }^{16}$ International law in this field can be traced back as far as 2,500 BC, when two Sumarian city-states of Laguash and Umma signed an agreement governing the Tigris River. ${ }^{17}$ Now there are believed to be over 400 international agreements relating to transboundary waters. ${ }^{18}$ This treaty practice and the related activities have led to the emergence of a significant body of customary rules and principles related to the management of transboundary waters, which are strongly reflected in the Convention on the Law of the Non-navigational Uses of International Watercourses (1997 UN Watercourses Convention). ${ }^{19}$

\footnotetext{
ISARM Atlas of Transboundary Aquifers.

FAO and UNEP Atlas of International Freshwater Agreements.

Wouters, Vinogradov and Magsig 2009 Yb Int'l Env L 97-134.

Ban Ki-Moon 2008 www.un.org.

Rieu-Clarke "International Freshwater Law" 243-257.

See generally McCaffrey 1992 AJPIL; Brown Weiss Evolution of International Water Law; Dellapenna and Gupta Evolution of the Law and Politics of Water.

18 FAO and UNEP Atlas of International Freshwater Agreements. See also Burchi and Mechlem Groundwater in International Water Law.

19 Convention on the Law of the Non-navigational Uses of International Watercourses (1997).
} 
While a notable body of international water law therefore exists, serious gaps remain. UN-Water - a body established to coordinate all UN Activities related to water - estimates that 158 of the world's 263 international freshwaters lack any type of cooperative management framework, and many others do not have the necessary mechanisms in place to cope with existing and future challenges, such as climate change, population growth, and food and energy security. ${ }^{20}$

Within this context, the purpose of this paper is to explore the linkages between the recently emerging paradigm of ecosystem services and international water law. More specifically, the paper seeks to examine whether an ecosystem services paradigm might help assist in the implementation of international water law. In achieving the latter aim, the paper also seeks to highlight the various prospects and pitfalls in applying such an ecosystem services paradigm to international water law.

\section{Towards an ecosystem approach...}

\subsection{Origins of an ecosystem approach}

In analysing the relationship between ecosystem services and international water law a distinction needs to be made, both temporally and in terms of definitions, as to the Ecosystem Approach and the emergence of planning and management related to the concept of ecosystem services, though the two are intrinsically linked.

Whilst elements of an ecosystem approach can be traced back many decades, the Ecosystem Approach owes its formal origins to the 1992 Convention on Biological Diversity, which recognised that conservation of biodiversity is a "common concern of human kind" and integral to progress on sustainable development. ${ }^{21}$ Along with the conservation of biodiversity itself, the Convention has two other main objectives - its sustainable use, and the sharing of benefits from the use of genetic resources.

\footnotetext{
UN-Water 2011 www.unwater.org.

Zawahri and McLaughlin 2011 International Studies Quarterly 835-858.

UN Convention on Biological Diversity (1992) (CBD) entered into force on 29 December 1993. 
At its second meeting in Jakarta in November 1995, the Conference of the Parties adopted the Ecosystem Approach as the primary framework for action under the convention, defining it as a strategy for the integrated management of land, water and living resources that promotes conservation and sustainable use in an equitable way. They recognised that this was much more than just about plants and animals, but was about people and their needs - for food, water, shelter, medicines and a healthy environment in which to live. In doing so, they also recognised a series of challenges that needed to be addressed; among them the uncertainties of the science - increasing our capacity to document and understand biodiversity, its value, and threats to it - and the need to improve policies, legislation, guidelines, and fiscal measures for regulating the use of biodiversity.

The Ecosystem Approach is based on 12 principles, though these can be grouped to reflect different aspects relating to management, to evidence-based science, to the involvement of stakeholders, and to societal choices. ${ }^{22}$ Clearly, these principles recognise that any adoption of this approach will entail dealing with the complexities of both human and bio-physical systems, and of having to make decisions with

22 See CBD 2010 www.cbd.int. The principles are as follows:

Principle 1:The objectives of management of land, water and living resources are a matter of societal choices

Principle 2: Management should be decentralized to the lowest appropriate level

Principle 3: Ecosystem managers should consider the effects (actual or potential) of their activities on adjacent and other ecosystems

Principle 4: Recognizing potential gains from management, there is usually a need to understand and manage the ecosystem in an economic context. Any such ecosystem-management programme should:

a. Reduce those market distortions that adversely affect biological diversity;

b. Align incentives to promote biodiversity conservation and sustainable use;

c. Internalise costs and benefits in the given ecosystem to the extent feasible.

Principle 5: Conservation of ecosystem structure and functioning, in order to maintain ecosystem services, should be a priority target of the ecosystem approach.

Principle 6: Ecosystems must be managed within the limits of their functioning.

Principle 7: The ecosystem approach should be undertaken at the appropriate spatial and temporal scales.

Principle 8: Recognizing the varying temporal scales and lag-effects that characterize ecosystem processes, objectives for ecosystem management should be set for the long term.

Principle 9: Management must recognize that change is inevitable.

Principle 10: The ecosystem approach should seek the appropriate balance between, and integration of, conservation and use of biological diversity.

Principle 11: The ecosystem approach should consider all forms of relevant information, including scientific and indigenous and local knowledge, innovations and practices.

Principle 12: The ecosystem approach should involve all relevant sectors of society and scientific disciplines. 
incomplete knowledge and great uncertainties. They go on to stress the need for adaptive management to take account of the uncertainites in the science, and in the dynamic and often unpredictable nature of ecosystem responses in time and space to both natural and human-induced pertebations. Along similar lines Brunée and Toope claim that

Simply put, an 'ecosystem approach' requires consideration of the whole system rather than individual components. Living species and their physical environments must be recognised as interconnected, and the focus must be on the interaction between different sub-systems and their responses to stresses resulting from human activity. Not only does interconnectedness imply management approaches that are broad-based in a spatial sense; it requires as well that human interaction with and use of the environment respect the need for maintaining 'ecosystem integrity', in other words, the system's capacity for self-organisation. ${ }^{23}$

Within the context of fresh water, an ecosystem approach has been considered to mean

assessing water availability (quantity and quality), identifying inter-relationships at the ecosystem level, predicting the environmental and social impact of any proposed action and evaluating the consequences before any decision is made on use. An ecosystem approach to freshwater management emphasises the dependence of maximising the sustainable use on the conservation of freshwater ecosystems and focuses on catchments or groundwater systems as the appropriate units of management. ${ }^{24}$

The latter explanation of an ecosystem approach within the freshwater context draws much from chapter 18 of Agenda 21, related to the Protection of the Quality and Supply of Freshwater Resources, as well as various other global policy statements. ${ }^{25}$

While the basis for an ecosystem approach can therefore be clearly found at the global policy level, is it also possible to conclude that such an approach is supported by law? In particular, for the purpose of this paper, does international law relating to transboundary freshwaters support such an approach?

Brunée and Toope 1994 Yearbook of International Environmental Law 41-76, 55.

IUCN and WWF 1998 www.uicmed.org.

UN 1992 www.un.org; UN 2005 www.un.org; ICWE 1992 www.wmo.int.
} 


\subsection{Is an ecosystem approach compatible with international water law? $?^{26}$}

Throughout the years alternative claims of state entitlement over international watercourses have been put forward. ${ }^{27}$ At one end of the spectrum, states - largely upstream - have claimed unlimited use of the waters of an international watercourse situated within their jurisdiction irrespective of the concerns of other - usually downstream - states. ${ }^{28}$ At the other end of the spectrum, states - often downstream - have claimed a right to receive the natural flows and conditions of an international watercourse. ${ }^{29}$ Primarily these claims have concerned protecting the economic interests of States vis-à-vis their neighbouring riparian States.

Given the need to find a compromise solution between these two extreme claims, state practice has largely followed the doctrine of limited territorial sovereignty, whereby States enjoy equal rights to the use of international watercourses and are subject to an obligation to respect the correlative rights of others. ${ }^{30}$

Within the context of international watercourses, the doctrine of limited territorial sovereignty has manifested itself in the principle of equitable and reasonable utilisation, which is considered to be the overarching principle that determines how uses and the protection of international watercourses are governed. ${ }^{31}$ Equitable and reasonable utilisation applies "... where the quantity or quality of the water is such that all the reasonable and beneficial uses of all watercourse states cannot be fully realised". ${ }^{32}$ The Wüttemberg case goes further in stating that:

The application of this principle [of equity] is governed by the circumstances of each particular case. The interests of the states in question must be weighed in an equitable manner against one another. One must consider not only the absolute

\footnotetext{
For a more extensive analysis of this question, see McIntyre 2004 RECIEL 1-14.

McCaffrey Law of International Watercourses 111-170.

See McCaffrey 1996 Natural Resources Journal 549-590.

Berber Rivers in International Law 19-22.

Tanzi and Arcari United Nations Convention 14-15.

Schwebel 1980 untreaty.un.org.

Schwebel 1980 untreaty.un.org.
} 
injury caused to the neighbouring state, but also the relation of the advantage gained by one to the injury caused to the other. ${ }^{33}$

Determining what is equitable therefore involves the weighing up of competing interests between states.

How, therefore, are ecosystems taken into account when determining what is equitable and reasonable? The factors that should be taken into account in such a weighing-up exercise are provided for in Article 6(1) of the UN Watercourses Convention, which stipulates that the

Utilisation of an international watercourse in an equitable and reasonable manner within the meaning of article 5 requires taking into account all relevant factors and circumstances, including:

(a)Geographic, hydrographic, hydrological, climatic, ecological and other factors of a natural character;

(b)The social and economic needs of the watercourse states concerned;

(c) The population dependent on the watercourse in each watercourse states;

(d)The effects of the use or uses of the watercourses in one watercourse state on other watercourse states;

(e)Existing and potential uses of the watercourse;

(f) Conservation, protection, development and economy of use of the water resources of the watercourse and the costs of measures taken to that effect;

(g)The availability of alternatives, of comparable value, to a particular planned or existing use. ${ }^{34}$

It goes on to state that "no use of an international watercourse enjoys inherent priority", and "all relevant factors are to be considered together and a conclusion reached on the basis of the whole". ${ }^{35}$ Does this therefore contradict an ecosystem approach, where priority is placed on the "conservation of ecosystem structure and functioning, in order to maintain ecosystem services"?

While a strict reading of 'equitable and reasonable utilisation' might lead to the conclusion that ecosystems are but one factor to be taken into account when

Würtemberg and Prussia v Baden Ann Dig 128 (1927-28).

34 Article 6 UN Convention on the Law of the Non-navigational Uses of International Watercourses (1997) (UN Watercourses Convention).

35 Articles 10(1) 6 UN Watercourses Convention.
} 
determining what is equitable and reasonable, it is important to account for the influence of emerging environmental norms on the development of international water law. Such an influence is reflected in Article 20 of the UN Watercourses Convention, which provides an important qualification to the principle that there should be no inherent priority. Pursuant to the Article states must "individually and, where appropriate, jointly, protect and preserve the ecosystems of international watercourses". ${ }^{36}$ Article 20 is thus described as "a simple, but potentially powerful, provision", ${ }^{37}$ which seeks to address the challenges faced by the existing and potential degradation of the ecosystems of international watercourses.

Article 20 requires watercourse states to 'protect' and 'preserve' the ecosystems of international watercourses. The obligation to 'protect' the ecosystems of international watercourses can be seen as "a specific application of the requirement contained in Article 5 [ie, the equitable and reasonable use principle] that watercourse states are to use and develop an international watercourse in a manner that is consistent with adequate protection thereof". ${ }^{38}$

In additional, the obligation to protect includes the duty to "protect those ecosystems from a significant threat of harm". ${ }^{39}$ Inherent in the notion of protection is therefore the need to adopt a precautionary approach. As stipulated in Principle 15 of the Rio Declaration, "in order to protect the environment, the precautionary approach shall be widely applied by states according to their capabilities. Where there are threats of serious or irreversible damage, lack of full scientific certainty shall not be used as a reason for postponing cost-effective measures to prevent environmental degradation". 40 Pursuant to the precautionary principle, a proportionate approach should be adopted that weighs up the degree of harm vis-àvis the level of scientific certainty. Where full scientific certainty is lacking but the

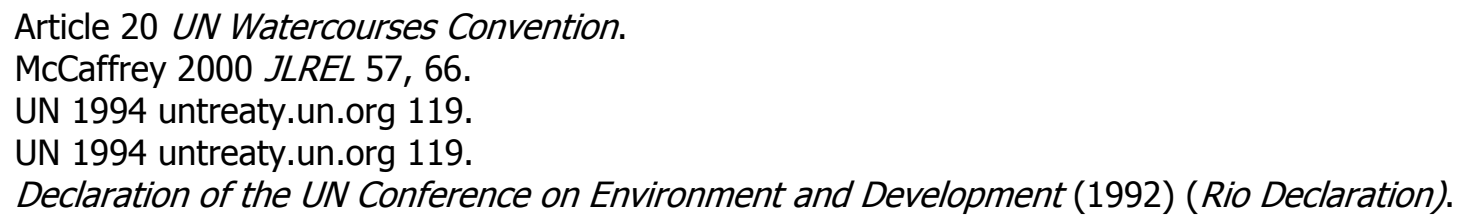


degree of harm is potentially imminent, serious or irreversible, precautionary measures might be justified. ${ }^{41}$

A further issue that should be considered in connection with Article 20 is the extent of the obligation to protect. McCaffrey observes that Article 20 is 'not qualified' in that "it does not say that the ecosystems must be protected only if failure to do so may harm another riparian state". ${ }^{42}$ However, the latter writer goes on to suggest that Article 20 amounts to "an obligation to exercise due diligence to protect and preserve water ecosystems". ${ }^{43}$ Similarly, Tanzi and Arcari claim that "although no express indication is provided either in Article 20 or in the relevant ILC commentary, it may be excluded that this obligation is one of an absolute character". ${ }^{44}$

The obligation to 'preserve' ecosystems of international watercourses applies to freshwater ecosystems in a 'pristine or unspoiled condition', ${ }^{45}$ and can be seen as subordinate to the obligation to protect. Schwebel introduced the notion within the work of the ILC through his discussion of 'wild and scenic watercourses'. ${ }^{46}$ He noted that preservation

involves the setting aside of a portion, or the entirety, of a stream, selected for its aesthetic beauty or its condition of being relatively unmodified by man: the native flora and fauna are typically abundant. Such free-running and unspoiled watercourses, so designated, will thus still be able to be experienced by future generations. ${ }^{47}$

Schwebel therefore proposed that

the Commission's articles on the non-navigational uses of international watercourses could be cast in such a way as to contemplate this emerging practice and to comprehend such preservation regimes as an element of a State's equitable

\footnotetext{
41 Sands Principles of International Environmental Law 269.

42 McCaffrey 2000 JLREL 66.

43 McCaffrey 2000 JLREL 66.

44 Tanzi and Arcari United Nations Convention 246. See also McIntyre 2004 RECIEL 9.

45 Tanzi and Arcari United Nations Convention 246; McIntyre 2004 RECIEL 9.

46 Schwebel 1982 untreaty.un.org 190.

47 Schwebel 1982 untreaty.un.org 190.
} 
participation in the development, use, protection and control of international watercourse systems. ${ }^{48}$

A further important feature of Article 20 of the UN Watercourses Convention is the inclusion of the phrase 'individually, and where appropriate, jointly'. This phrase recognises that in certain circumstances states will not be able to act alone in protecting the ecosystem of international watercourses, but must work with other states sharing a particular watercourse on an equitable basis. The requirement to act jointly where appropriate can therefore be seen as an extension of the obligation contained in Article 5(2) for watercourse states to "participate in the use, development and protection of an international watercourse in an equitable and reasonable manner"; and the requirement under Article 8 that watercourse states cooperate in order to attain optimal utilisation and adequate protection of an international watercourse. ${ }^{49}$ In summarising this obligation, the ILC stipulates that

the duty to participate equitably in the protection and preservation of the ecosystems of an international watercourse is not to be regarded as implying an obligation to repair or tolerate harm that has resulted from another watercourse State's breach of its obligations under the draft articles. But the general obligation of equitable participation demands that the contributions of watercourse States to joint protection and preservation efforts be at least proportional to the measure in which they have contributed to the threat or harm to the ecosystems in question. ${ }^{50}$

Joint protection and perseveration of the ecosystems of international watercourses therefore often requires significant cooperation between states.

Ultimately, given the above discussion it is possible to maintain that at least the basis for an ecosystem approach can be found within international water law, although much of the detail is left out. It can be clearly seen though that in their own respective languages the 12 principles of the Ecosystem Approach and the approach of international law to the equitable and reasonable usage of a shared or common resource take in many ways a similar starting point, and share many common features. Indeed a comparison of the 12 Principles of the Ecosystem 
Approach with the seven factors listed in Article 6(1) of the 1977 UN Watercourses Convention shows just how well linked these two are - a link that is further developed in Article 20 of the latter Convention. Perhaps most significant in relation to Article 20 is its implication that boundaries are demarcated on the basis of ecosystems rather than a specific location or territorial area per se. Linkages between land and water, a key aspect of the ecosystem approach, are therefore reflected in Article 20. Also, in its emphasis on 'joint' protection and preservation, where necessary, Article 20 picks up on another important aspect of the ecosystem approach, namely that an ecosystem should be managed as a single unit.

However, the current status of the law raises some unanswered questions. What is perhaps less clear is whether international law can or does recognise an 'intrinsic right' of the environment itself to exist and function, and if so, in what manner it addresses this right. This can be seen in Article 20 of the UN Watercourses Convention where interpretations differ on whether the obligation contained therein is absolute, i.e., protection of an ecosystem per se, or is a due diligence obligation contingent on harm being caused to neighbouring watercourse states. Another way of looking at this issue is in terms of the proof of environmental harm. In that regard Tarlock observes that "we still think of transboundary injuries primarily as immediate air, water, and soil pollution rather than as ecosystem degradation", and "the law remains undeveloped and uncertain when it comes to the assessment of ecosystem damage"..$^{51}$

\subsection{An ecosystem approach vis-à-vis an ecosystem services approach}

Having concluded that at least the basis of an ecosystems approach can be found in the key provisions of international water law, this section of the paper goes on to 
consider how the more specific ecosystem services paradigm links to international water law.

At the outset it is important to make a distinction between the Ecosystem Approach and the subsequent and more focussed attention on ecosystem services - although the two concepts are intrinsically linked. The Ecosystem Approach recognises that new forms of valuation and assessment are needed, and that different sectors of society and different cultures will see ecosystems very much within their own particular environmental, economic and societal needs. Consistent with the core principle of international water law (equitable and reasonable use) the ecosystem approach goes on to stress that ecosystems should be managed in a fair and equitable manner for the tangible and intangible benefits they bring to humans, and for their intrinsic value. The MA and TEEB are instructive in this regard.

What the Ecosystem Approach does not do itself, and what the MA and TEEB start to do is to develop clear ideas and potentially a new conceptual framework for the detailed assessment and management of ecosystems in terms of the values and services that flow from ecosystems to humans. The MA was not the first such interpretation of this concept of ecosystem services. Its early origins can be traced back to the $1970 \mathrm{~s}^{52}$, but as debate widened in the following decades, it has become the dominant interpretation of what is sometimes now claimed to be a new paradigm.

The MA recognises that one of the main reasons for damage to natural ecosystems is their conversion to other less biologically diverse land-uses, such as intensive agriculture to support human development. Our current systems of decision-making undervalue the non-market costs and benefits of such changes, while also underplaying inter-generational costs at the expense of short-term gains. The externalities of changes to natural systems, such as the drainage of wetlands, are often hidden, and those who privately gain often do so at the expense of others 
'downstream'- often indigenous populations, the wider public in general, or crossboundary states.

The MA assessed the consequences of changes to ecosystems for human well-being. The assessment was conducted a global level and involved more than 1350 experts. It provided for the first time a detailed appraisal of the state and trends in the world's ecosystems, as well as the scientific knowledge upon which action should be taken to use them more sustainably.

In relation to freshwater ecosystems, the MA found that forest and mountain ecosystems act as sources for the largest supply of renewable fresh water, serving at least two thirds of the world's population - thus justifying the need to account for the linkages between land and water practices. However, it is estimated that a third of the world's watersheds have lost more than $75 \%$ of their original forest cover. ${ }^{53}$ This linkage between the upstream provision of services (in this instance within the forestry sector) and the downstream utilisation of services thus provided (often water-related) has now become widely recognised and can be seen to operate on very large, often transboundary scales; indeed, even on a global scale, where forest management and carbon regulation are concerned. It has become the basis for many novel schemes to re-connect providers and beneficiaries through markets and payments for ecosystem services. ${ }^{54}$ Whilst many of these schemes have their origins in much smaller-scale national and sub-national initiatives governed by the laws of individual state, increasingly this is recognised as being of relevance across state boundaries and watercourses. The upstream and downstream may well be thousands of miles apart across international boundaries, the providers and the beneficiaries not even directly connected to impacts on the same ecosystem services.

Revenga et al Watersheds of the World 45-46.

See especially Landell-Mills and Porras Silver Bullet or Fool's Gold?; Bond and Mayers Fair Deals for Watershed Services. 
The MA also warned that too great a use - primarily to meet agricultural needs - has led to competition between human freshwater use and the water requirements of freshwater ecosystems. The key consequences of such competititon have been changes in the flow regime, the transport of sediments and chemical pollutants, the modification of the habitat, and the disruption of the migration routes of aquatic biota - which in turn jeopardise a range of additional ecosystem services. The MA further observes that the supply of fresh water continues to be reduced by 'severe pollution', which has in turn impaired the ability of ecosystems to provide clean and reliable sources of fresh water. The MA has also claimed that engineering practices that satisfy the demand for reliable sources of fresh water and flood control have stabilised flows for irrigation, flood control, drinking water and hydroelectricty, but often at the cost of the fragmentation and destruction of habitat, the loss of species, the proliferation of health issues associated with stagnant water, and the loss of sediments and nutrients destined to support coastal ecosystems, such as mangroves, with their important fisheries. ${ }^{55} \mathrm{~A}$ key underlying theme of the MA was to question the value of the above practices and trends vis-à-vis the often under appreciated and under valued services that ecosystems provide.

Perhaps most significantly, the MA has introduced to a wider audience the conceptual framework that identifies the various types of services that healthily functioning ecosystems provide, and the need to recognise, value and protect these. More recently at an individual state level the UK National Ecosystem Assessment has taken this approach even further and pursued it in much greater detail, ${ }^{56}$ and further developments in knowledge and understanding are bound to follow.

The MA is taken to be the dominant interpretation of and basis for this new conceptual framework that promotes the idea of ecosystem services. In doing so, it goes beyond the management and scientific principles of the Ecosystem Approach and focuses firmly on the connectivity between functioning ecosystems, the services they produce, and human well-being. It is the ecosystem processes and 
intermediate services that provide people with a range of goods and services that, together with further inputs of capital and knowledge, produce what is described as human well-being. However, this simple definition hides a burgeoning debate on typologies and terminologies, and increasing confusion as to linkages between services ${ }^{57}$ Fundamental to this view, though, is the inseparability of those that rely on the environment (for food, shelter, recreation, culture, etc) and the physical state of the ecosystems and ecosystem processes that underpin it.

The MA identifies four categories of ecosystem service:

- Supporting - e.g. soil formation, pollination, photosynthesis, biodiversity itself

- Provisioning - e.g. food, water supply, timber

- Regulating - e.g. climate control, flood control, water quality

- Cultural - e.g. recreation, spiritual values.

Others have suggested that there is a fundamental difference between the nature of the supporting services, which essentially underpin the other three classes, and that they therefore have little immediate relationship to human well-being. Another way of presenting these relationships has also been proposed - that of a cascade linking ecosystem structures and processes through the functioning of ecosystems to the services people derive from them. ${ }^{58}$ As with the classification of supporting services as being somehow different from the other three services, the paradigm of the cascade has a potential added attraction in that a perceived separation between intrinsic ecosystem functioning and the services people derive from it may be more amenable to legal dissection and interpretation. At least it raises the possibility of a theoretical separation between legislation to protect the environment per se and that to protect states' and individuals' access to services provided by that environment.

57 See for instance Jax 2007 Acta Biotheoretica 341-355; Wallace 2008 Biological Conservation 353354. 
This framing has led to a focus on attempts to identify these services, to map them, to map those suppliers and beneficiaries (and losers), to value them (especially in non-market terms), and to consider how they might be 'traded' when it comes to decisions as to how and which to favour ahead of other competing services. ${ }^{59}$ In particular, it has led to the development and consideration not so much of the absolute value that such services provide, ${ }^{60}$ as to marginal values and the potential to develop scenarios that allow stakeholders to choose between different futures.

The UK National Ecosystem Assessment takes the process further than the MA, with a detailed account at the individual state level of ecosystem services, trends and drivers, and ending with a range of scenarios about potential futures and the policy options that might lead to their respective development or avoidance. ${ }^{61}$ The chapter on water and wetlands highlights that throughout history the integrity and effective functioning of freshwater ecosystems have been compromised and their multiple service provision 'traded off' against management actions to deliver specific provisioning services, such as food production, with little understanding of the true cost or the identity of the losers from this changed environment. ${ }^{62}$

Ultimately, this focus on ecosystem services therefore calls for and looks to provide the framework for better decision making. Such a contribution is two-fold: firstly, the ecosystem services framework seeks to ensure that the full range of services that ecosystems provide is taken into account; and secondly, where trade-offs between difference services are inevitably made, such an approach calls for that to be done in a way that identifies and engages with all relevant stakeholders. However, while the theroy is conceptually sound, within the transboundary context the identification and valuation of a full range of ecosystem services, making decisions on trade-offs

\footnotetext{
59 See for example the many references and full discussion of economic valuation in Bateman et al 2011 Environmental and Resource Economics 177-218..

60 Although Costanza et al's 1997 valuation puts global ecosystem services at US\$33 trillion per year, compared to global gross national product at around US $\$ 18$ trillion per year (Costanza et al 1997 Nature 253).

61 Bateman et a/ "Valuing Changes in Ecosystem Services" 1265-1307.

62 Maltby et al "Freshwaters" 295-365.
} 
between services, and engaging all relevant stakeholders within these processes would be highly problematic.

\subsection{Ecosystems services, law and transboundary freshwaters - prospects and pitfalls}

A number of prospects and pitfalls may be identified when considering the linkages between ecosystem services, law and transboundary freshwaters, including the problem structure, assessing equity, property rights and market mechanisms, institutional capacity and stakeholder participation. The purpose of this section is to highlight some of these prospects and pitfalls, with a view to recognising the need for further research through case studies at the transboundary basin level.

\subsubsection{Problem structure and freshwater ecosystems}

Four out of five people live downstream of, and are served by renewable freshwater services, representing $75 \%$ of the total supply. ${ }^{63}$

The 'upstream-downstream' nature of freshwater ecosystems provides perhaps the most compelling need to adopt an ecosystem services framework. Changes in the uses of transboundary freshwater ecosystems both upstream and downstream can have a range of impacts on the supporting, provisioning, regulating and cultural services within a freshwater ecosystem: impacts that may be felt far from the location of the use, and quite possibly across administrative and political boundaries. Numerous examples can be offered. For instance, changing natural forest to managed forest can lead to a decrease in freshwater flow and lower long-term groundwater recharge; and converting land from forest to pasture or agricultural land can lead to a significant increase in surface water run-off, greater erosion and sediment loss, lower long-term groundwater recharge, and greater likelihood and magnitude of floods. ${ }^{64}$ 
These examples from the forestry sector highlight two important aspects that should be considered when examining the linkages between international water law and ecosystem services. Firstly, land-based practices can have a significant impact on freshwater ecosystems and international watercourses. Secondly, and given the significant number of transboundary freshwater ecosystems, these impacts and linkages will quite often more than not have an international dimension. Consequent on these two aspects, a third feature is that the providers and beneficiaries/losers from changes to ecosystem service delivery (for example through changes in land management) may be difficult to identify, will often be in different states, and may be working or relying upon these services for their existence, influence over the delivery of which they individually have no control.

One way to examine the challenges faced by the transboundary nature of freshwater ecosystems is to consider them as a collective action problem. ${ }^{65}$ The disconnect between geophysical and political boundaries means that uses in one territory may lead to 'externalities' in another jurisdiction. ${ }^{66}$ This parallels the disconnect and lack of accounting for externalities that has driven habitat destruction and the loss of publically enjoyed regulating and cultural services, at the expense of private gain for provisioning services (eg intensive agriculture) at a more local scale.

At the transboundary level, Hardin predicted that in such circumstances a 'tragedy of the commons' will ensue, wherein each state unilaterally seeks to get the most out of the shared natural resource while mimising the cost of (over)exploitation. ${ }^{67}$ It is not surprising that McCaffrey and Neville therefore conclude that sovereignty "is a doctrine that is not well suited to regulating relations between two or more states that share the same resource". 68

\footnotetext{
65 Benvenisti 1999 AJIL 384-415. .

66 Dombrovsky Conflict, Cooperation and Institutions 47.

67 Hardin 1968 Science 1243-1248.

68 McCaffrey and Neville "Politics of Sharing Water" 19.
} 
However, significant literature supports the notion that in certain conditions a 'tragedy of the commons' scenario can be averted and collective action over shared resources fostered in a way that is both optimal and sustainable. ${ }^{69}$ Benvenisti, for instance, observes that

\begin{abstract}
with regard to common pool resources, the possibility of excluding outsiders provides an opportunity for the limited number of insiders to coordinate their activities and, thereby, avert a tragedy of their commons. In other words, with transboundary resources such as ecosystems, which are international common pool resources, there is a palpable potential for collective action between the co-owner states that will provide an optimal and sustainable use of the resource. ${ }^{70}$
\end{abstract}

What conditions must therefore be in place in order to foster cooperation between states over common pool resources?

Cooperation is most likely to arise where states perceive that they have a common interest and that the benefits or the payoffs of collective action are greater than those arising from unilateral action. Here there may be an important role for the use of an ecosystem services framework to highlight the multiplicity of the benefits that freshwater ecosystems and their collective protection provide. Some commentators even go further and argue that

a stronger focus on Ecosystem Services would produce new benefit opportunities, such as biodiversity benefits and increased resilience to extreme climate events such as floods and droughts, which would complement more traditional benefits such as hydropower and navigation. ${ }^{71}$

In this regard, Sadoff and Grey identify four types of benefits:

environmental benefits to the 'river' (e.g. improved water quality, conserved biodiversity); economic benefits from the 'river' (e.g. increased food and energy production); reduction of costs because of the 'river' (e.g. reduced geo-political tensions, enhanced flood management); and benefits beyond the 'river' (catalysing wider cooperation and economic integration). ${ }^{\mathbf{7 2}}$

\footnotetext{
Ostrom Governing the Commons.

Benvenisti Sharing Transboundary Resources 33.

Roy, Barr and Venema Ecosystem Approaches 7.

Sadoff and Grey 2004 Water Policy 392.
} 
Interestingly, this classification mirrors the ecosystem service concept, in that the first element, environmental benefits to the river, can be seen as the supporting services of the Millennium Assessment ecosystem services model. Ultimately an ecosystem services approach therefore has the potential to optimise the range of benefits within a particular transboundary freshwater ecosystem. However, it should be recognised that trade-offs will still have to be made, and 'some people' will be 'winners' and others 'losers' in the 'transition'. ${ }^{73}$

There is therefore an important role for law to play in obliging, or at least encouraging, states to collectively govern transboundary freshwater ecosystems as international common pool resources, and in an optimal and sustainable manner.

The strongest basis for a collective action approach under international law can be found in the theory of 'community of interest'. ${ }^{74}$ This theory suggests that water should be considered as 'common property' between states. ${ }^{75}$ Such an approach has been endorsed in terms of navigation by the Permanent Court of Justice in the 1929 decision concerning the Territorial Jurisdiction of the International Commission of the River Oder, ${ }_{1}^{76}$ and extended to non-navigational uses by the 1997 International Court of Justice Case concerning the Gabcikovo-Nagymaros Project. ${ }^{77}$ In the last case, the ICJ stipulated that

Czechoslovakia, by unilaterally assumming control of a shared resource, and thereby depriving Hungary of its right to an equitable and reasonable share of the natural resources of the Danube ... failed to respect the proportionality which is required by international law. ${ }^{78}$

Ruhl, Kraft and Lant Law and Policy of Ecosystem Services 250.

Benvenisti Sharing Transboundary Resources, 43-63.

McCaffrey Law of International Watercourses 148.

Territorial Jurisdiction of the International Commission of the River Oder (UK, Czech, Den, Fr, Ger, Swed v Pol) (Judgement) [1929] PCIJ (Ser A) No 23.

77 Case Concerning the Gabčíkovo-Nagymaros Project (Hung v Slovak) Sep 25 1997, 37 ILM 162 (1998).

78 Case Concerning the Gabčkovo-Nagymaros Project (Hung v Slovak) Sep 25 1997, 37 ILM 162 (1998) para 85. 
There is an important distinction to be made here between states having an interest in a transboundary freshwater ecosystem, and their collectively governing that ecosystem as a single unit. Perhaps the clearest articulation of this is in Article 5(1) of the 1997 UN Watercourses Convention, which obliges states to utilise their international watercourse in an equitable and reasonable manner, with a view to attaining optimal and sustainable utilisation thereof and benefits therefrom. ${ }^{79}$ This provision would appear to provide states with two options. Firstly, they can utilise the waters of a transboundary watercourse unilaterally, but those actions must be equitable and reasonable. Secondly, states can choose to utilise waters collectively in order to maximise the benefits from collective action.

A key conclusion from this section is therefore that the adoption of an ecosystem services framework is reliant on states treating transboundary freshwaters as an international common pool resource. In some ways, it is this common pool (the underlying supporting services) that provides the basis from which regulating, provisioning and cultural services flow. It is from these latter services that states gain and individuals achieve a better quality of life (human well-being). However, international law does not currently provide a strong legal basis to oblige collective action in the governance of transboundary freshwater ecosystems.

\subsubsection{Assessing equity}

As noted previously, when determining what is equitable and reasonable Article 6 of the 1997 UN Watercourses Convention lists a range of non-exhaustive factors relating to (a) the physical characteristics of the resources (eg geographic, hydrographic, hydrological, climatic, ecological); (b) the social and economic needs of the watercourse states and their populations; (c) the effects of existing and potential uses of the watercourse; (d) ecosystem protection; (e) and the availability of alternative uses of comparable value to existing or planned uses. ${ }^{80}$ However, international law is virtually silent on the way in which such factors and 
circumstances should be determined. Furthermore, only general guidelines are given on the relative weighting of factors. Article 6(3) thus states that "the weight to be given to each factor is to be determined by its importance in comparison with that of other relevant factors", and Article 10 stipulates that "no use of an international watercourse enjoys inherent priority over other uses".

By focussing on the range of services (supporting, provisioning, regulating, and cultural) that freshwater ecosystems provide and also the linkages between these services, the ecosystem services paradigm arguably provides a more sophisticated analytical framework for use in identifying relevant factors. In the past, short-term gains over the use of the freshwater ecosystems, for intensive agriculture or extensive shrimp farming to name just two examples, have come at the costs of arguably more valuable services that freshwater ecosystems provide. ${ }^{81}$ Utilising an ecosystem services framework - within the context of determining all of the relevant factors and cirucumstances - could therefore provide the potential for a more rigorous and complete assessment of a more complete range of freshwater ecosystem services.

However, the identification and valuation of ecosystem services is in some ways still in its relative infancy. Whilst the conceptual basis has been well articulated, its translation into implementation is far more challenging. ${ }^{82}$ It is complicated by arguments over definitions, measurement techniques, boundaries, scale, societal values, trade-offs, non-market goods and, not least of all, uncertainties about the nature of the link between biological diversity itself and the services that flow from ecosystems. ${ }^{83}$ At a very basic level, the identification and valuation of ecosystem services has been approached either from a bio-physical science perspective or from that of the social sciences, though increasingly studies have attempted to bring these together in a multidisciplinary systems approach. One can see these almost as the two starting points of the "cascade" model of ecosystem services - one being

\footnotetext{
See for instance the study by Vilardy et a/ 2011 Hydrological Sciences Journal 1423-1435. Cook and Spray (2012) Journal of Environmental Management 93-100.

See for instance Norgaard 2010 Ecological Economics 1210-1227.
} 
that of the physical and biological landscapes and the other being that of human well-being and the quality of life - with the aim of integrating these to provide an overall assessment.

The remote sensing technology required for the assessment of large-scale transboundary catchments can be used to map habitats very effectively. Ground surveys can therefore be very well characterised and defined. To this extent, mapping transboundary wetland systems (at least above ground) is well advanced. Physical, chemical and biological states and indeed some processes can be measured, and although this technology can go further than more traditional measurements of ecosystem health based solely on the 'state' of the environment (the number of species, the area of the habitat, the level of the defined parameters) our ability to measure the services that flow from these habitat patches is less clear. Equally, we remain uncertain as to the nature of the relationship between environmental change and the resulting change in ecosystem services, which may in many instances be non-linear and even irreversible.

Whilst there have been technical and methodological advances in the bio-physical sciences that enable us to better define ecosystems, there have also been improvements in our understanding of the value of these services and their relationship to human well-being ${ }^{84}$ However, while many values can be assessed in terms of money, others have proved less amenable to such an approach (and for some audiences even attempting to place a price on nature is seen as unacceptable). Certainly, such elements as the spiritual value of places, which is often best developed in indigenous populations, are hard to account for, as are the non-use or existence values of biodiversity itself, even through stated preference models. However, initiatives such as the UK National Ecosystem Assessment have

84 The literature on the valuation of ecosystem services is now vast, both for market and nonmarket goods and services, and there is a wealth of proven methodologies for establishing marginal values in relation to comparisons between existing situations and different observed or planned scenarios. See for example Fisher and Turner 2008 Biological Conservation 1167-1169. 
developed methodologies for recognising these and, importantly, for focussing on the marginal changes in these values. ${ }^{85}$

Equally important has been the approach to valuation based on participatory GIS mapping and detailed stakeholder engagement. Increasingly this has involved joint data collection by and with local communities, with regular meetings and feedback sessions to collectively analyse and interpret the results in terms of their effects on human well-being. ${ }^{86}$

Within the context of a transboundary ecosystem a fundamental requirement for determining ecosystem services will be the exchange of data and information, particularly where the methodologies for collection and interpretation may be contested. The value of obliging states to regularly exchange data and information is well summed up by Bourne, who notes that, there are two reasons why it is desirable for states to exchange information about all matters relating to the international drainage basins that they share. In the first place, a drainage basin is a geographical entity and its flowing waters bind states together physically, so that whatever affects the volume or the quality of the waters in one state will often affect it on another, perhaps so minimally that the effect will be imperceptible or perhaps so seriously that it will be disastrous. Co-basin states, then, are interdependent. Since, this is so, it is essential for sound planning of the development of any part of the basin to know both the factors of the natural characteristics of the entire basin and the plans of development that are intended of its parts. The second reason favouring exchange of information is that knowledge about the basin promotes cooperation between states and thus leads to higher efficiency in the exploitation of the resources of the basin. ${ }^{87}$

Bateman et a/ 2011 "Economic Values from Ecosystems" 1067-1151.

See for example Hamerlynck et al 2011 Hydrological Sciences Journal 1436-1451.

Bourne 1972 UTL 160-161. 
Article 9 of the UN Watercourse Convention obliges watercourse states to exchange readily available data and information on a regular basis. ${ }^{88}$ Such data and information includes the condition of the watercourse, and in particular that of a "hydrological, meteorological, hydrogeological and ecological nature", and "related to the water quality as well as related forecasts". ${ }^{89}$ Numerous treaty practices support the obligation to exchange data and information. ${ }^{90}$ Whilst not speaking to the transboundary nature specifically, principles 10 and 7 of the Ecosystem Approach also recognise that "all forms of relevant information, including scientific and indigenous and local knowledge, innovations and practices" should be considered, and should be undertaken "at the appropriate spatial and temporal scale".

Closely related to the obligation to regularly exchange data and information is the requirement that states must give notification of planned measures. Therefore, according to Article 12 of the UN Watercourses Convention

\begin{abstract}
before a watercourse State implements or permits the implementation of planned measures which may have a significant adverse effect upon other watercourse States, it shall provide those states with timely notification thereof. Such notification shall be accompanied by available technical data and information, including the results of any environmental impact assessment, in order to enable the notified States to evaluate the possible effects of planned measures. ${ }^{91}$
\end{abstract}

The primary purpose of Article 12 , and the customary law obligation to notify of planned measures, is so that all potentially affected states have an opportunity to determine if a planned use is consistent with the obligation to utilise transboundary freshwaters in an equitable and reasonable manner. In this regard Article 12 provides a procedural trigger by which to weigh up all of the relevant factors and circumstances. This could also provide the opportunity for the structured assessment of marginal change, through the development of a series of potential ecosystem service futures or scenarios.

\footnotetext{
88 UN Watercourses Convention.

89 UN Watercourses Convention.

90 For a survey of applicable law see Rieu-Clarke International Law and Sustainable Development 142-143.

91 UN Watercourses Convention.
} 
Coupled with the obligation to notify is the requirement to conduct a transboundary environmental impact assessment (TEIA). It would appear that the assessment and evaluation of possible transboundary environmental impacts of a planned project has not become a binding obligation under customary international law. The International Court of Justice endorsed this customary law requirement in its Pulp Mills Decision, where it claimed that EIAs "may now be considered a requirement under general international law", with regard to activities that "may have a significant adverse impact in a transboundary context". While the obligation has remained open and imprecise as to the content of any EIA, it does provide a basis by which the impact of planned measures on the full range of ecosystem services and their benficiaries may be assessed.

\subsubsection{Property rights, payments and market mechanisms}

In order for decision-makers to utilise the ecosystem services framework, there must be an effective system in place by which actual or potential beneficiaries can secure rights to freshwater services, or obligations can be imposed for their provision. ${ }^{92}$ There is clearly a myriad of property rights issues that must be addressed when seeking to use the ecosystem services framework at the national level, ${ }^{93}$ but this paper will attempt to highlight considerations at the transboundary level only.

Some of the challenges in defining property rights at a transboundary level have already been highlighted above. It has been noted that while the overarching principle of equitable and reasonable use does not conflict with the use of an ecosystem services framework, it offers limited guidance. In particular, it is difficult to precisely determine how individual or combined ecosystem services might be weighed against other relevant factors and circumstances. Similarly, while Article 20 of the 1997 UN Watercourses Convention specifically obliges states to protect the

\footnotetext{
92 Aylward et a/"Freshwater Ecosystem Services" 225.

93 See Ruhl, Kraft and Lant Law and Policy of Ecosystem Services 87-126.
} 
ecosystems of international watercourses, questions remain over the extent of that protection. For example, what is the threshold of harm to be tolerated? Is it enough that harm is caused to an freshwater ecosystem, or must there also be a transboundary element to that harm?

A complicating factor will also be the legal status of various ecosystem services (provisioning, regulating, cultural, supporting), which will tend to encompass a range of both public and private goods. A 'bundle' of property rights held by individuals, groups, or the state may therefore exist within a particular freshwater ecosystem context. ${ }^{94}$ Provisioning services such as forest and agricultural products (and water) may be clearly designated as private property rights, and often assigned to individuals but mostly companies. Economic theory dictates that once the rights have been assigned, right holders will tend to maximise the utility of a resource. ${ }^{95}$ Moreover, the use of such provisioning services has an impact on regulating, supporting and cultural services, which may constitute a mixture of public or private goods. Further complications arise as the holders of such rights to develop provisioning services (such as intensive agriculture) may be international companies operating from outside the territorial state and its legislation, whereas the affected populations may be local, or themselves located across state boundaries elsewhere.

While clearly definable and enforceable property rights are therefore fundamental, it could be asked if international law has suffient determinacy to effectively support an approach based on the ecosystem services framework at the transboundary level.

One opportunity to strengthen property rights pertaining to ecosystem services at the transboundary level is through a focus on determining and protecting ecosystem water requirements. ${ }^{96}$ As noted by the Millennium Ecosystem Assessment ${ }^{97}$

\footnotetext{
Aylward et a/"Freshwater Ecosystem Services" 225.

Duraiappah Markets for Ecosystem Services 4.

McIntyre Environmental Protection of International Watercourses 292.

Aylward et al "Freshwater Ecosystem Services" 222.
} 
determining how much water can be allocated to human uses or distributed through flow stablisation (such as dam construction) without loss of ecosystem integrity is central to an understanding of how freshwater ecosystems support human well being through the range of provisioning, supporting and regulating services.

A need to protect 'environmental flows' - ie, water that is left in a river ecosystem, or released into it, for the specific purpose of managing the condition of the river ecosystem - has therefore begun to gain increasing recognition in law and policy. ${ }^{98}$ In terms of the ecosystem services classification, this might be seen as one of the key supporting services - essentially maintaining the water cycle and the underlying biological diversity of the ecosystem itself.

The need to "ensure stream flows adequate to protect the biological, chemical, and physical integrity of international watercourses, including their estuarine zones"99 is reflected in a range of treaty practice. For instance, the 2002 Inco-Maputo Agreement provides details pertaining to flow regimes and recognises "the need to ensure water of sufficient quantity with acceptable quality to sustain the watercourse and their associated ecosystem". ${ }^{100}$ Also the 1995 Agreement on the Cooperation for the Sustainable Development of the Mekong River Basin obliges states to maintain, 'acceptable minimum monthly flows' to protect the ecological integrity of the Mekong. ${ }^{101}$ In addition, the need to protect 'environmental flows' can be found in national legislation. The 1998 South African Water Act, for instance, utilises the concept of the 'reserve', which is defined as being "the quantity and

See Scanlon and Iza 2003 Yb Int'l Env L 81-100. See also Article 19 Draft International Covenant on Environment and Development (2004), which stipulates that "parties must, take all appropriate measures, in particular through conservation and management of water resources, to ensure the availability of a sufficient quantity of water to satisfy basic human needs and to maintain aquatic systems" (IUCN 2004 www.i-c-e-l.org).

99 Utton and Utton "Adequate Stream Flows" 387.

100 Article 9 Tripartite Interim Agreement for Co-operation on the Protection and Sustainable Utilisation of the Water Resources of the Incomati and Maputo Watercourse (2002): "the need to ensure water of sufficient quantity with acceptable quality to sustain the watercourse and their associated ecosystems".

101 Article 6 Agreement on the Cooperation for the Sustainable Development of the Mekong River Basin (1995) requires parties to provide for 'acceptable minimum monthly flows' to protect the ecological integrity of the Mekong. 
quality of water required ... to protect aquatic ecosystems in order to secure ecologically sustainable development and use of the relevant water resource". ${ }^{102}$

While the concept of environmental flows might go some way to protecting ecosystem services, two key caveats are worthy of note. Firstly, a question still remains over the 'additional' services that may be shared between users (states) in an equitable manner. Secondly, the determination of environmental flows is essentially a societal decision that reflects a desired condition of an ecosystem informed by data and information concerning the hydrology and ecosystem services. ${ }^{103}$ An effective process by which to determine environmental flows in any one given context will therefore be heavily reliant on collaborative initiatives being in place amongst scientists, natural resource managers and stakeholders. Such processes speak to the need for strong institutional capacity, supported by mechanisms to facilitate 'effective' stakeholder engagement.

An additional factor that should be considered alongside property rights is the role of market mechanisms and ecosystem services. Markets for ecosystem services are increasingly being recognised as playing an important role in the sustainable use of ecosystem services, and more recently for alleviating poverty. ${ }^{104}$ Examples of such markets include carbon sequestration offsets, tradable development rights, tradable quota systems, eco-labelling and environment certification and bioprospecting. ${ }^{105}$

Sadoff has even suggested that payment for ecosystem services, which has become increasingly popular in the national context, could be used as a basis for financial transboundary water cooperation ${ }^{106}$ In this regard, it is suggested that the cooperative management of transboundary waters could be seen as an international public good. International and non-basin states might even pay for 'ecosystem and security services' within major transboundary river basins, as an alternative to the

\footnotetext{
102 National Water Act 36 of 1998.

103 Aylward et al"Freshwater Ecosystem Services" 222.

104 Duraiappah Markets for Ecosystem Services; Bond and Mayers Fair Deals for Watershed Services.

105 Duraiappah Markets for Ecosystem Services; 10-12.

106 Sadoff et al Share 77.
} 
'paternalistic donor-recipient model'. ${ }^{107}$ Payment for ecosystem services schemes at the transboundary level has also been explored by the UN Economic Commission for Europe, ${ }^{108}$ which has developed guidelines for the establishment and operation of such a system. However, it is difficult to find evidence of actual practice within transboundary freshwater ecosystems. For instance, in a recent study of payments for watershed services in developing coutries, 95 schemes at various stages of development were identified, with the only 'international' schemes not being in transboundary watersheds, but rather being donor-led projects that support payment for watershed services in particular countries. ${ }^{109}$

Clearly a major challenge in establishing such schemes will be to establish transparent and fair property rights that are capable of encompassing the full range of ecosystem services and transcend the national level - otherwise markets will fail to regulate environmental services in an optimal and sustainable manner. ${ }^{110}$ Institutions must play an instrumental role in this regard.

\subsubsection{Institutions matter}

The adoption of an ecosystem services approach within the context of transbounday freshwater ecosystems will ultimately require sophisticated institutional mechanisms alongside standardised scientific techniques, models and methodologies (including quality assurance) by which to identify the range of services and address competing interests in those services through the necessary valuations and trade-offs. Institutions must play a pivotal role in such a process, both in terms of gathering sufficient data and information on the ecosystem, managing trade-offs between different users and interests, and engaging all relevant actors in the assessment, adoption and monitoring of decisions.

\footnotetext{
107 Sadoff et al Share 77.

108 UNECE Recommendations on Payments.

109 Porras, Grieg-Gran and Neves All that Glitters 27.

110 For a critique of environmental markets, see Graham, "Mythology of Environmental Markets". 
The MA stresses the need to work across boundaries, whilst also noting that "six of seven ineffective responses to ecosystem problems could be attributed to the lack of ... multilevel collaboration". ${ }^{111}$ Existing institutions tend to have a narrow focus both in terms of geographic scale and sectoral bias. ${ }^{112}$ The limitations of such an approach are well summed up by the World Resource Institute:

Today's institutions... usually focus on a single sector such as forestry or finance at a single political level or geographical scale and often on a short timeframe. A community group or social network is concerned about local livelihoods, a national agency about planning national development, and a secretariat of an international convention about improving the state of specific types of resources such as biodiversity, migratory species, or wetlands globally. At every level, institutions are handicapped by their limited mandate, capacity or incentive to cooperate across geographical or political boundaries, or to consider the longer timeframes often needed to manage ecosystem services effectively. If ecosystem services are to be sustained to support human well-being, decision makers need to address drivers and effects of change that emerge at different levels and time scales. This will require working outside of traditional boundaries in multidisciplinary settings. ${ }^{113}$

However, establishing an all-encompassing institution to govern ecosystem services constitutes a significant challenge. As noted in the MA

the water cycle plays so many roles in the climate, chemistry, and biology of Earth, it is difficult to define it as a distinctly supporting, regulating, or provisioning service. Precipitation falling as rain or snow is the ultimate source of water supporting ecosystems. Ecosystems, in turn, control the character of renewable freshwater resources for human well-being by regulating how precipitation is partitioned into evaporative, recharge, and runoff processes. Together with energy and nutrients, water is arguably the centerpiece of the delivery of ecosystem services to humankind. ${ }^{114}$

How, then, can institutions address these issues of scale? As one commentator notes, "many environmental problems originate from [the] mismatch between the scale at which the ecological processes occur, the scale at which decisions are made, and the scale of institutions for decision-making". ${ }^{115}$

\footnotetext{
111 Aylward et al "Freshwater Ecosystem Services" 214.

112 Irwin and Ranganathan Restoring Nature's Capital 19-44.

113 Irwin and Ranganathan Restoring Nature's Capital 19.

114 Aylward et al "Freshwater Ecosystem Services" 222.

115 Irwin and Ranganathan Restoring Nature's Capita/ 26.
} 
The need for a river basin focus has been reflected within a range of law and policy instruments. ${ }^{116}$ River basin organisations have thus evolved from a narrow and sectoral focus on water bodies and point sources of pollution to a focus on entire watersheds based on inter-sectoral approaches. ${ }^{117}$ However, state practice related to the establishment of transboundary institutions is somewhat limited. Dombrovsky, for instance, identifies only 62 basins with international river basin organisations. ${ }^{118}$

Such a limited record of joint institutions should be contrasted with their importance. McCaffrey observes that

the management of international watercourse systems through joint institutions is not only an increasingly common phenomenon, but also a form of co-operation between watercourse States that is almost indespensible if anything approaching optimum utilisation and protection of the system of waters is to be attained. ${ }^{119}$

Similarly, the International Law Association's Water Resources Committee ${ }^{120}$ observed that "the need for an instiutionalised co-ordination of competitive and concurrent needs and interests is deeply felt by the international community and is evidenced by the considerable number of agreements concluded in this respect._" Despite the recognised need for joint institutions, customary international law provides only soft provisions in this regard. The International Law Association observed that "analysis of conventional law, state practice, and of the opinion of most qualified publicists does not seem to provide evidence of the formation of a general international custom obliging States interested in the conservation and development of an international drainage basin to set up joint management agencies". ${ }^{121}$ Similarly, Article 8(2) of the 1997 UN Watercourses Convention stipulates that

watercourse States may consider the establishment of joint mechanisms or commissions, as deemed necessary by them, to faciliate cooperation on relevant

EU Water Framework Directive (2000); ICWE 1992 www.wmo.int; UN 1992 www.un.org.

Aylward et al "Freshwater Ecosystem Services" 229-232.

Dombrovsky Conflict, Cooperation and Institutions 24.

Schwebel 1980 untreaty.un.org para 7.

Bogdanović (ed) International Law of Water Resources 19.

Bogdanović (ed) International Law of Water Resources 19.
} 
measures and procedures in the light of experience gained through cooperation in existing joint mechanisms and commissions in various regions.

In addition, under Article 24 of the UN Watercourses Convention

watercourse states shall... enter into consultations concerning the management of an international watercourse, which may include the establishment of a joint management mechanism. ${ }^{122}$

Perhaps the most explicit obligation to establish joint institutions can be found in the 1992 UN ECE Helsinki Convention, whereby

\begin{abstract}
riparian parties shall on the basis of equality and reciprocity enter into bilateral or multilateral agreements or other arrangements, where these do not yet exist, or adapt existing ones, where necessary to eliminate the contradictions with the basic principles of this Convention, in order to define their mutual relations and conduct regarding the prevention, control and reduction of transboundary impact. ${ }^{123}$
\end{abstract}

The Convention goes on to stipulate that "the agreements or arrangements ... shall provide for the establishment of joint bodies". ${ }^{124}$

Within the transboundary context, a major challenge therefore remains to establish institutions that have the necessary roles, responsibilities and resources to support the valuation of ecosystems services, take decisions concerning trade-offs between services, and engage all relevant stakeholders within such processes. Moreover, the need for institutional coordination from the local level to the transboundary river basin level provides an added complication that must be addressed if an ecosystem services approach is to be effectively adopted throughout a transboundary freshwater ecosystem.

\footnotetext{
122 UN Watercourses Convention.

123 Convention on the Protection and Use of Transboundary Watercourses and International Lakes (1992) (Helsinki Convention).

124 Article 9(2) Helsinki Convention.
} 


\subsubsection{Stakeholder participation}

Whilst institutions at the basin level might arguably play an effective co-ordinating and integrating role within the context of transboundary freshwater ecosystems, there is also a need to engage with a range of governance levels. Ensuring that stakeholders from the local, national and regional level are effectively engaged in decision making procedures will be crucial. Ganoulis and Skoulikaris provide a conceptual model for implementing integrated transboundary water resources management, within which they identify stakeholder consultation and collaboration as the basis for effective management. ${ }^{125}$ Whilst not specifically dealing with ecosystem services, like other studies this study focuses on an iterative approach whereby transboundary diagnostic analysis, data collection, modelling and scenario planning are shared with stakeholders prior to implementation. It thus encompasses the key elements of principles 7, 11 and 12 of the Ecosystems Approach relating to the appropriate scale of management, to the use of all forms of information (including local knowledge), and to the involvment of all relevant sectors of society.

The nature of institutions is also a key challenge, as while state controlled or sponsored institutions have a role to play, effective governance requires a bottomup approach, and one that often sits more easily with non-governmental organisations, working at the interface between state and society. Such 'trusted intermediaries' can often work across national or sub-national boundaries with a greater flexibility than state bodies, building local consensus around environmental protection and enhancement, and ultimately ecosystem service delivery. ${ }^{126}$

In this regard, Principle 10 of the Rio Declaration stipulates that "environmental issues are best handled with the participation of all concerned citizens, at the relevant level", and similarly the Ecosystems Approach of the CBD recognises that

\footnotetext{
125 Ganoulis \& Skoulikaris.(2011) "A Conceptual mode/" 99-103.

126 For a review of the need for new governance models to handle processes of complex change, see Duit et al 2010 Global Environmental Change 363-368; and for collaborative approaches to watershed management, see Sabatier et al (eds) Swimming Upstream.
}

$46 / 212$ 
management should be decentralized to the lowest appropriate level and 'involve all relevant sectors of society....'. The MA goes on to observe that ${ }^{127}$

\begin{abstract}
a key focus for improving participatory processes is to help level the playing field through measures to increase the transparency of information; improve the representation of marginalised stakeholders; engage them upfront in the establishment of policy objectives and priorities for the allocation of freshwater services, with which specific projects should be consistent; and create a space for deliberation and learning that accommodates multiple perspectives.
\end{abstract}

There are major challenges to establishing an effective participatory process around ecosystem services, their valuation and potential trade-offs. Assessing stakeholder views and desires is a highly subjective business and will vary across scale and time, and between different cultures and locations. These challenges to participation have been documented elsewhere. ${ }^{128}$

However, a key concern in relation to transboundary freshwater ecosystems relates to the current status of international law in this regard. As noted by Bruch and others, 'people often have little or no opportunity to participate in watershed decisions that affect them, particularly when they live along international watercourses.' ${ }^{129}$ Stakeholder participation in the governance of transboundary waters is a relatively recent phenomenon in international law. Despite the adoption of the Rio Declaration in 1992, the 1997 UN Watercourses Convention is almost silent on the rights of non-state actors.

Some treaties at the regional and basin level do include provision for stakeholder participation at the transboundary level. For instance, the 1992 UN ECE Helsinki Convention requires that "information concerning the conditions of transboundary waters, measures taken or planned to be taken to prevent, control and reduce transboundary impact, and the effectiveness of those measures, is made available to the public. ${ }^{130}$ The EU Water Framework Directive goes futher by requiring not only

\footnotetext{
Aylward et a/"Freshwater Ecosystem Services" 227.

Rieu-Clarke et a/"Science-Policy-Stakeholder Interface" 29-50.

Bruch et a/'"From Theory to Practice" 3.

Article 16(1) Helsinki Convention.
} 
that the public has access to data and information related to the development of river basin management plans, but Member States must encourage the active involvement of all interested parties in the implementation of the Directive, in particular through the production, review and updating of River Basin Management Plans. ${ }^{131}$ Other examples exist where specific basin treaty law has provided some provision for public participation. ${ }^{132}$ However, it must be noted that such a practice is more of the exception than the norm, a fact which raises a serious question about whether or not international law supports this key aspect in its potential utilisation of an ecosystem services framework.

In furthering the role of stakeholders in decision making concerning transboundary freshwater ecosystems it might also be useful to explore linkages with procedural human rights, such as the rights to information, freedom of speech and public participation, and of access to effective remedies. ${ }^{133}$ General provisions on political participation and freedom of assembly, opinion and expression can be found in the Univeral Declaration on Human Rights, which is not legally binding per se but is reflective of customary international law, and the International Covenant on Civil and Political Rights. ${ }^{134}$ Also, the Arhus Convention on Accession to Information, Public Participation in Decision-Making and Access to Justice in Environmental Matters, while limited in geographic scope to the UN Economic Commission for Europe, provides a standard by which to formulate legal rules and principles related to stakeholder engagement.

\section{Conclusion}

The implementation of the established ecosystem-based approaches adopted by the Convention on Biological Diversity, the Convention on Wetlands, the Food and Agriculture Organization, and others could substantially improve the future condition of water-provisioning services by balancing economic development, ecosystem

\footnotetext{
131 Article 14(1) EU Water Framework Directive (2000).

132 See Rieu-Clarke International Law and Sustainable Development 143-146.

133 Greiber et al Conservation with Justice.

134 See generally Blanco and Razzaque 2009 Hum Rts Q 692-720.
} 
conservation, and human well-being objectives. ${ }^{135}$

The above analysis demonstrates that there is potential value in considering the paradigm of ecosystem services alongside the development of international water law. In terms of equity, an ecosystem services framework encourages states to account for a wider range of ecosystem services when determining and reconciling their competing interests. While, traditionally, the identification of 'relevant' factors and circumstances has largely focused on provisioning services, such as water uses for consumptive and non-consumptive uses (drinking, irrigation, transport and hydropower), adopting the framework of the ecosystem services paradigm would offer an opportunity to identify a wider range of services and benefits that (transboundary) ecosystem services provide, and in doing so to identify and hence protect the disparate interests of a wide range of dispersed stakeholders

However, as the previous section has shown, there are some significant shortcomings in international law that may potentially preclude the effective uptake and implementation of an ecosystem services framework at the transboundary level. States have often shown a reluctance to treat transboundary freshwater ecosystems as an international common pool resource. Such a reluctance is reflected in weak arrangements related to joint institutions, property rights and stakeholder participation: three areas that are fundamental to the successful implementation of an ecosystem services approach. That said, there would appear to be developments in treaty practice at the regional and basin-specific levels that may provide a good indication of how the law might evolve.

Ultimately, a key conclusion to be drawn from this paper is that ecosystem services and international water law are mutually reinforcing concepts. As this paper has demonstrated, international water law - or more importantly its effective implementation - can benefit from an ecosystem services approach; and conversely 
the effective implementation of an ecosystem services approach is contingent on the necessary legal and regulatory frameworks being in place. 


\section{Bibliography}

Allan and Rieu-Clarke 2010 Irrigation and Drainage Systems

Allan A and Rieu-Clarke A "Good Governance and IWRM - A Legal Perspective" 2010 Irrigation and Drainage Systems 239-248

Aylward et a/ "Freshwater Ecosystem Services"

Aylward B et al "Freshwater Ecosystem Services" in Hassan R, Scholes R and Ash N Ecosystem and Human Well-being: Current State and Trends (Island Press Washington DC 2005) 213-255

Bateman et al 2011 Environmental and Resource Economics

Bateman IJ et al "Economic Analysis for Ecosystem Service Assessments" 2011 Environmental and Resource Economics 177-218

Bateman et al "Economic Values from Ecosystems"

Bateman IJ et al "Economic Values from Ecosystems" in The UK National Ecosystem Assessment Technical Report (UNEP-WCMC Cambridge 2011) $1067-1151$

Bateman et al "Valuing Changes in Ecosystem Services"

Bateman IJ et al "Valuing Changes in Ecosystem Services: Scenario Analyses" in The UK National Ecosystem Assessment Technical Report (UNEP-WCMC Cambridge 2011) 1265-1307

Benvenisti 1996 AJIL

Benvenisti E "Collection Action in the Utilization of Shared Freshwater: The Challenges of International Water Resources Law" 1996 AJIL 384-415

Benvenisti Sharing Transboundary Resources

Benvenisti E Sharing Transboundary Resources - International Law and optimal Resource Use (Cambridge University Press Cambridge 2002) 
Berber Rivers in International Law

Berber FJ Rivers in International Law (Stevens London 1959)

Biswas 2004 Water International

Biswas AK "Integrated Water Resources Management: A Reassessment - A Water Forum Contribution" 2004 Water International 248-256

Biswas 2008 Journal of Water Resources Development

Biswas AK "Integrated Water Resources Management: Is it Working?" 2008 International Journal of Water Resources Development 5-22

Blanco and Razzaque 2009 Hum Rts $Q$

Blanco E and Razzaque J "Ecosystem Services and Human Well-Being in a Globalised World: Assessing the Role of Law" 2009 Hum Rts Q 692-720

Bogdanović (ed) International Law of Water Resources

Bogdanović S (ed) International Law of Water Resources - Contribution of the International Law Association (1954-2000) (Kluwer Law International The Hague 2004)

Bond and Mayers Fair Deals for Watershed Services

Bond I and Mayers J Fair Deals for Watershed Services: Lessons from a Multicountry Action-learning Project (IEED London 2010)

Bourne 1972 UTLJ

Bourne CB "Procedure in the Development of International Drainage Basins" 1971 UTLJ 172-206

Brown Weiss Evolution of International Water Law

Brown Weiss E The Evolution of International Water Law (Martinus Nijhoff The Hague 2009) 
Brunée and Toope 1994 Yearbook of International Environmental Law

Brunée J and Toope S "Environmental Security and Freshwater Resources: A Case for International Ecosystem Law" 1994 Yearbook of International Environmental Law 41-76

Bruch et al "From Theory to Practice"

Bruch C et al "From Theory to Practice: An Overview of Approaches to Involving the Public in International Watershed Management" in Bruch C et al (eds) Public Participation in the Governance of International Freshwater Resources (United Nations University Tokyo 2005) 3-18

Burchi and Mechlem Groundwater in International Water Law

Burchi S and Mechlem K Groundwater in International Water Law (FAO Rome 2005)

Cook and Spray 2012 Journal of Environmental Management

Cook BR and Spray CJ "Ecosystem Services and Integrated Water Resource Management: Different Paths to the Same End?" 2012109 Journal of Environmental Management 93-100

Costanza et al 1997 Nature

Costanza R et al "The Value of the World's Ecosystem Services and Natural Capital" 1997 Nature 253-260

Dellapenna and Gupta Evolution of the Law and Politics of Water

Dellapenna JW and Gupta JW The Evolution of the Law and Politics of Water (Springer Berlin 2009)

Dombrovsky Conflict, Cooperation and Institutions

Dombrovsky I Conflict, Cooperation and Institutions in International Water Management - An Economic Analysis (Edward Elgar Cheltenham 2007) 
Duraiappah Markets for Ecosystem Services

Duraiappah AK Markets for Ecosystem Services - A Potential Tool for Multilateral Environmental Agreements (IISD Winnipeg 2007)

Duit et a/2010 Global Environmental Change

Duit A et al "Governance, Complexity and Resilience" 2010 Global Environmental Change 363-368

FAO and UNEP Atlas of International Freshwater Agreements

FAO and UNEP Atlas of International Freshwater Agreements (UNEP Nairobi 2002)

Feldman and Blaustein 2007 Env't L Rep

Feldman IR and Blaustein RJ "Ecosystem Services as a Framework for Law and Policy" 2007 Env't L Rep 1-34

Fisher and Turner 2008 Biological Conservation

Fisher B and Turner RK "Ecosystem Services: Classification for Valuation" 2008 Biological Conservation 1167-1169

Global Water Partnership Technical Advisory Committee Integrated Water Resources Management

Global Water Partnership Technical Advisory Committee Integrated Water Resources Management (GWP Stockholm 2000)

Ganoulis \& Skoulikaris A Conceptual Model

Ganoulis J \& Skoulikaris Ch (2011) A Conceptual Model for Implementing Integrated Transboundary Water Resources Management (ITWRM) Proc $2^{\text {nd }}$ International Symposium on Building Knowledge Bridges for a Sustainable Water Future, Panama, 21-24 November, 2011 (Panama Canal Authority (ACP) and UNESCO 2011) 99-103 
Graham "Mythology of Environmental Markets"

Graham N "The Mythology of Environmental Markets" in Grinlinton DP and Taylor P (eds) Property Rights and Sustainability (Martinus Nijhoff Leiden 2011) $149-166$

Greiber et al Conservation with Justice

Greiber $\mathrm{T}$ et al Conservation with Justice - A Rights-based Approach (IUCN Gland 2009)

Haines-Young and Potschin "Links Between Biodiversity"

Haines-Young R and Potschin M "The Links Between Biodiversity, Ecosystem Services and Human Well-being" in Rafaelli DG and Frid CJ (eds) Ecosystem Ecology: A New Synthesis (Cambridge University Press Cambridge 2010) 110139

Hamerlynck et a/2011 Hydrological Sciences Journal

Hamerlynck $\mathrm{O}$ et al "To Connect or Not to Connect? Floods, Fisheries and Livelihoods in the Lower Rufiji Floodplain Lakes, Tanzania" 2011 Hydrological Sciences Journal 1436-1451

Hardin 1968 Science

Hardin G "The Tragedy of the Commons" 1968 Science 1243-1248

Hassan, Scholes and Ash Ecosystem and Human Well-being

Hassan R, Scholes R and Ash N Ecosystem and Human Well-being: Current State and Trends (Island Press Washington DC 2005)

Irwin and Ranganathan Restoring Nature's Capital

Irwin F and Ranganathan J Restoring Nature's Capital - An Action Agenda to Sustain Ecosystem Services (WRI Washington DC 2007) 
ISARM Atlas of Transboundary Aquifers

ISARM Atlas of Transboundary Aquifers (UNESCO Paris 2009)

Jax 2007 Acta Biotheoretica

Jax K "Can we Define Ecosystems? On the Confusion Between Definition and Description of Ecological Concepts" 2008 Acta Biotheoretica 341-355

Kumar Economics of Ecosystems

Kumar $\mathrm{P}$ The Economics of Ecosystems and Biodiversity: Ecological and Economic Foundations (London Earthscan 2010)

Landell-Mills and Porras Silver Bullet or Fool's Gold?

Landell-Mills N and Porras I Silver Bullet or Fool's Gold? A Global Review of Markets for Forest Environmental Services and their Impacts on the Poor (IIED London 2002)

Maltby and Acreman 2011 Hydrological Sciences Journal

Maltby E and Acreman MC "Ecosystem Services of Wetlands: Pathfinder for a New Paradigm" 2011 Hydrological Sciences Journal 1341-1359

Maltby et al "Freshwaters"

Maltby, Ormerod, Acreman, Blackwell, Durance, Everard, Morris \& Spray "Freshwaters - Openwaters, Wetlands and Floodplains" in The UK National Ecosystem Assessment Technical Report (UNEP-WCMC Cambridge 2011) 295-365

McCaffrey 1992 AJPIL

McCaffrey SC "The Evolution of the Law of International Watercourses" 1992 AJPIL 87-111 
McCaffrey 1996 Natural Resources Journal

McCaffrey SC "The Harmon Doctrine One Hundred Years Later: Buried, not Praised" 1996 Natural Resources Journal 549-590

McCaffrey 2000 JLREL

McCaffrey SC "An Overview of the U.N. Convention on the Law of the Nonnavigational Uses of International Watercourses" 2000 JLREL 55-75

McCaffrey Law of International Watercourses

McCaffrey SC The Law of International Watercourses $2^{\text {nd }}$ ed (Oxford University Press London 2007)

McCaffrey and Neville "Politics of Sharing Water"

McCaffrey SC and Neville K "The Politics of Sharing Water: International Law, Sovereignty, and Transboundary Rivers and Aquifers" in Wegerich $\mathrm{K}$ and Warner J The Politics of Water - A Survey (Routledge London 2010) 18-44

McIntyre 2004 RECIEL

McIntyre O "The Emergence of an 'Ecosystem Approach' to the Protection of International Watercourses under International Law" 2004 RECIEL 1-14

McIntyre Environmental Protection of International Watercourses

McIntyre O Environmental Protection of International Watercourses (Ashgate London 2007)

Mitchell 2005 Environment and Planning

Mitchell B "Integrated Water Resources Management: Institutional Arrangements and Land-use Planning" 2005 Environment and Planning 13351352 
Norgaard 2010 Ecological Economics

Norgaard RB "Ecosystem Services: From Eye-opening Metaphor to Complexity Blinder" 2010 Ecological Economics 1219-1227

Ostrom Governing the Commons

Ostrom E Governing the Commons - The Evolution of Institutions and Collective Action (Cambridge University Press Cambridge 1990)

Porras, Grieg-Gran and Neves All that Glitters

Porras I, Grieg-Gran M and Neves N All that Glitters - A Review of Payments for Watershed Services in Developing Countries (IIED London 2008)

Revenga et al Watersheds of the World

Revenga $\mathrm{C}$ et al Watersheds of the World: Ecological Value and Vulnerability (Worldwatch Institute Washington DC 1988)

Rieu-Clarke "International Freshwater Law"

Rieu-Clarke A "International Freshwater Law" in Shawkat A and Techera E Handbook of International Environmental Law (Routledge London 2012) 243257

Rieu-Clarke International Law and Sustainable Development

Rieu-Clarke A International Law and Sustainable Development (IWA London 2005)

Rieu-Clarke et a/"Science-Policy-Stakeholder Interface"

Rieu-Clarke A et al "The Science-Policy-Stakeholder Interface and Participation" in Gooch GD and Stalnacke P (eds) Science, Policy and Stakeholders in Water Management (Earthscan London 2010) 29-50 
Roy, Barr and Venema Ecosystem Approaches

Roy D, Barr J and Venema $\mathrm{H}$ Ecosystem Approaches in Integrated Water Resources Management (UNEP and IISD Nairobi 2011)

Ruhl, Kraft and Lant Law and Policy of Ecosystem Services

Ruhl JB, Kraft SE and Lant CL The Law and Policy of Ecosystem Services (Island Press Washington DC 2007)

Sabatier et al (eds) Swimming Upstream

Sabatier PA et al (eds) Swimming Upstream. Collaborative Approaches to Watershed Management (MIT Press Cambridge MA 2005)

Sadoff et al Share

Sadoff C et al Share - Managing Water Across Boundaries (IUCN Gland 2008)

Sadoff and Grey 2002 Water Policy

Sadoff CW and Grey D "Beyond the River: The Benefits of Cooperation on International Rivers" 2002 Water Policy 389-403

Sands Principles of International Environmental Law

Sands P Principles of International Environmental Law $2^{\text {nd }}$ ed (Oxford University Press Oxford 2003)

Scanlon and Iza 2003 Yb Int'l Env L

Scanlon J and Iza A "International Legal Foundations for Environmental Flows" 2003 Yb Int'l Env L 81-100

Smith et al Pay

Smith M et al Pay - Establishing Payments for Watershed Services (IUCN Gland 2006) 
Tanzi and Arcari United Nations Convention

Tanzi A and Arcari M The United Nations Convention on the Law of International Watercourses (Kluwer The Hague 2001)

Tarlock "Ecosystems"

Tarlock D "Ecosystems" in Bodansky D, Bruneé J and Hey E The Oxford Handbook of International Environmental Law (Oxford University Press Oxford 2007) 574-598

Turner, Georgiou and Fisher Valuation of Ecosystem Services

Turner RK, Georgiou S and Fisher B Valuation of Ecosystem Services: The Case of Multi-functional Wetland (Earthscan London 2008)

UK National Ecosystem Assessment Technical Report

UK National Ecosystem Assessment Technical Report (UNEP-WCMC Cambridge 2011)

UNECE Recommendations on Payments

UNECE Recommendations on Payments for Ecosystems Services in Integrated Water Resources Management (UN New York 2007)

Utton and Utton "Adequate Stream Flows"

Utton AE and Utton J "Adequate Stream Flows" in Bogdanović S (ed) International Law of Water Resources - Contribution of the International Law Association (1954-2000) (Kluwer Law International The Hague 2004) 387-413

Vilardy et al 2011 Hydrological Sciences Journal

Vilardy $\mathrm{S}$ et al "Relationships Between Hydrological Regimes and Ecosystem Services Supply in a Caribbean Coastal Wetland: A Social-ecological Approach" 2011 Hydrological Sciences Journal 1423-1435 
Vörösmarty et al "Freshwater"

Vörösmarty $\mathrm{CJ}$ et al "Freshwater" in Hassan R, Scholes R and Ash N Ecosystem and Human Well-being: Current State and Trends (Island Press Washington DC 2005)

Wallace 2008 Biological Conservation

Wallace K "Ecosystem Services: Multiple Classifications or Confusion?" 2008 141 Biological Conservation 353-354

Wouters, Vinogradov and Magsig 2009 Yb Int'l Env L

Wouters PK, Vinogradov S and Magsig BO "Water Security, Hydrosolidarity and International Law: A River Runs Through It..." 2009 Yb Int'l Env L97-134

Zawahri and McLaughlin 2011 International Studies Quarterly

Zawahri NA and McLaughlin S "Fragmented Governance in International Rivers: Negotiating Bilateral Versus Multilateral Treaties" 2011 International Studies Quarterly 835-858

\section{Register of legislation}

National Water Act 36 of 1998

\section{Register of international documents}

Agreement on the Cooperation for the Sustainable Development of the Mekong River Basin (1995)

Convention on the Protection and Use of Transboundary Watercourses and International Lakes (1992) (Helsinki Convention)

Declaration of the UN Conference on Environment and Development (1992) (Rio Declaration)

Draft Articles on the Law of the Non-navigational Uses of International Watercourses (1994) 
Draft International Covenant on Environment and Development (2004)

Dublin Statement on Water and Sustainable Development (1992)

EU Water Framework Directive (2000)

Tripartite Interim Agreement for Co-operation on the Protection and Sustainable Utilisation of the Water Resources of the Incomati and Maputo Watercourse (2002)

UN Convention on Biological Diversity (1992)

UN Convention on the Law of the Non-navigational Uses of International Watercourses (1997)

\section{Register of cases}

Case Concerning the Gabčḱkovo-Nagymaros Project (Hung v Slovak) Sep 25 1997, 37 ILM 162 (1998)

Territorial Jurisdiction of the International Commission of the River Oder (UK, Czech, Den, Fr, Ger, Swed v Pol) (Judgement) [1929] PCIJ (Ser A) No 23

Würtemberg and Prussia v Baden Ann Dig 128 (1927-28)

\section{Register of Internet sources}

Ban Ki-Moon 2008 www.un.org

Ban Ki Moon 2008 Address as Prepared for Delivery to the Davos Work Economic Forum www.un.org/apps/news/infocus/sgspeeches/search_full.asp?statID =177 [date of use 19 Feb 2012]

CBD 2010 www.cbd.int

Convention on Biological Diversity 2010 COP 5 Decision V/5 www.cbd.int/decision/cop/?id=7148 [date of use 19 Feb 2012] 
ICWE 1992 www.wmo.int

International Conference on Water and the Environment 1992 Dublin Statement on Water and Sustainable Development www.wmo.int/pages/prog/hwrp/documents/english/icwedece.html [date of use 19 Feb 2012]

IUCN 2004 www.i-c-e-l.org

International Union for Conservation of Nature 2004 Draft International Covenant on Environment and Development www.i-c-e-l.org/indexen.html [date of use 18 Feb 2012]

IUCN and WWF 1998 www.uicmed.org

International Union for Conservation of Nature and World Wide Fund for Nature 1998 Strategic Approaches to Freshwater Management: Background Paper - The Ecosystem Approach www.uicnmed.org/web2007/cdflow/conten/5/pdf/5-2-RAMSARGuidelines/Strategic-Freshwater-Manag/Strategic-Approach.htm [date of use 18 Feb 2012]

Schwebel 1980 untreaty.un.org

Schwebel S 1980 Second Report on the law of the non-navigational uses of international watercourses untreaty.un.org/ilc/documentation/english/a_cn4_332.pdf [date of use 19 Feb 2012]

Schwebel 1982 untreaty.un.org

Schwebel S 1982 Third Report on the Law of the Non-navigational Uses of International Watercourses untreaty.un.org/ilc/documentation/english/ a_cn4_348.pdf [date of use 19 Feb 2012] 
UN 1994 untreaty.un.org

United Nations 1994 Draft Articles on the Law of the Non-navigational Uses of International Watercourses

untreaty.un.org/ilc/documentation/english/a_cn4_|493.pdf [date of use 19 Feb 2012]

UN 1992 www.un.org

UN 1992 UNCED Agenda 21 www.un.org/esa/dsd/agenda21 [date of use 18 Feb 2012]

UN 2005 www.un.org

UN 2005 Johannesburg Plan of Action www.un.org/esa /sustdev/documents/WSSD_POI_PD/English/POIToc.htm [date of use 18 Feb 2011]

UN-Water 2011 www.unwater.org

UN-Water 2011 Transboundary Waters: Sharing Benefits, Sharing Responsibilities www.unwater.org/downloads/UNW_TRANSBOUNDARY.pdf [date of use 21 Sep 2011]

\section{List of abbreviations}

AJIL American Journal of International Law

AJPIL Austrian Journal of Public International Law

CBD UN Convention on Biological Diversity

Env't L Rep Environmental Law Reporter

EU European Union

FAO Food and Agriculture Organization

Hum Rts Q Human Rights Quarterly

ICWE International Conference on Water and the Environment

ISARM Internationally Shared Aquifer Resources Management 
IUCN International Union for Conservation of Nature

IWRM Integrated Water Resource Management

JLREL Journal of Land, Resources and Environmental Law

MA Millennium Ecosystem Assessment

RECIEL Review of European Community and International Environmental Law

TEEB The Economics of Ecosystem and Biodiversity

TEIA Transboundary Environmental Impact Assessment

UN United Nations

UNCED United Nations Conference on Environment and Development

UNEP United Nations Environment Programme

UTL] University of Toronto Law Journal

WWF World Wide Fund for Nature

Yb Int'l Env L Yearbook of International Environmental Law 